\title{
In-vitro evaluation of dye leakage of an MTA apical barrier at varying setting times
}

\author{
Mark Daniel Richey \\ West Virginia University
}

Follow this and additional works at: https://researchrepository.wvu.edu/etd

\section{Recommended Citation}

Richey, Mark Daniel, "In-vitro evaluation of dye leakage of an MTA apical barrier at varying setting times" (2008). Graduate Theses, Dissertations, and Problem Reports. 2617.

https://researchrepository.wvu.edu/etd/2617

This Thesis is protected by copyright and/or related rights. It has been brought to you by the The Research Repository @ WVU with permission from the rights-holder(s). You are free to use this Thesis in any way that is permitted by the copyright and related rights legislation that applies to your use. For other uses you must obtain permission from the rights-holder(s) directly, unless additional rights are indicated by a Creative Commons license in the record and/ or on the work itself. This Thesis has been accepted for inclusion in WVU Graduate Theses, Dissertations, and Problem Reports collection by an authorized administrator of The Research Repository @ WVU. For more information, please contact researchrepository@mail.wvu.edu. 


\title{
In-Vitro Evaluation of Dye Leakage of an MTA Apical Barrier at Varying Setting Times
}

MARK DANIEL RICHEY, DMD

\author{
Thesis submitted to the \\ School of Dentistry \\ At West Virginia University \\ In Partial Fulfillment of the Requirements \\ For the Degree of \\ Master of Science \\ In \\ Endodontics \\ Michael D. Bagby, D.D.S., Ph.D., Chair \\ C. Russell Jackson, D.D.S., M.S. \\ Thomas F. Razmus, D.D.S, M.S.
}

Department of Endodontics

Morgantown, WV

2008 


\section{ABSTRACT \\ In-Vitro Evaluation of Dye Leakage of an MTA Apical \\ Barrier at Varying Setting Times}

\section{Mark Daniel Richey}

The purpose of this study was to compare the dye leakage of an MTA apical barrier after immediate placement, 1 hour, 4 hours, 24 hours, and 1 week of setting time. One hundred twenty single-rooted extracted teeth were accessed and the apical three millimeters resected. The teeth were instrumented with 0.06 tapered Brasseler EndoSequence series rotary instruments to the apex. The same instrument was then placed in the apical opening and advanced to D16, resulting in an apical opening of $1.36 \mathrm{~mm}$. The teeth were randomly assigned to the five test groups, and ten teeth each were placed in positive and negative control groups. Teeth were placed in flower arrangement foam, rinsed with 5.25\% sodium hypochlorite, dried, and a five millimeter apical barrier of MTA was introduced to the apex. After allowing the MTA to set to the specific test time, the tooth was filled with gutta percha and Cavit. An acrylic barrier was placed over the entire tooth except for the resected root end, and each tooth was placed in methylene blue dye. They were then demineralized, dehydrated, and cleared to allow visualization of the leakage. The amount of leakage was evaluated with a measuring microscope in mm. Data were analyzed using a one-way ANOVA and Tukey’s HSD test. Results indicated significantly more leakage occurred in the immediate placement and 1 hour setting time groups compared to the 4 hours, 24 hours, and 1 week setting time groups $(\mathrm{p}<0.05)$. While the immediate placement group exhibited more leakage $(4.2 \mathrm{~mm})$ than the 1 hour setting time group $(3.8 \mathrm{~mm})$, the difference was not significantly different. In addition, the difference in leakage between the 4 hour $(1.7 \mathrm{~mm}), 24$ hour $(1.7 \mathrm{~mm})$, and 1 week $(1.6 \mathrm{~mm})$ setting time was not significantly different. In this in-vitro model, allowing an MTA apical barrier to set for at least 4 hours appears to be most beneficial. 


\section{DEDICATION}

To my family...

Thank you for your support over the years and for helping me reach my dream.

Melissa...

You mean the world to me. Thank you for being there for me through all these years of education and for believing in me.

Abigail...

I’m so lucky you've come into my life. 


\section{ACKNOWLEDGEMENTS}

I would like to acknowledge and thank the following people:

Dr. C. Russell Jackson, for accepting me into the program and for your dedication to the school after all these years. You truly are one of a kind and I look up to you for that.

Dr. Mike Bagby, for helping put together my thesis from beginning to end, and for covering the clinic so that we could travel to CE courses.

Dr. Thomas Razmus, for serving on my thesis committee and your continued dedication to education.

Dr. Ryan Burleson, I couldn't have asked for a better co-resident. You've made the last two years very entertaining. I'll miss the laughs you gave me on a daily basis.

Dr. Kent McBride, for being a great friend and for all the good times. I wish you and Jeff the best in your "partnership".

Dr. Nic Taylor, git er done Nic! Thanks for making me feel welcome my first year as a resident.

Dr. Bryant Stowe, for being so kind and for giving me great advice. You're pretty much my best friend.

Dr. Albert Tomsic, Jr., thanks for sharing your knowledge of coffee and your thoughts on the ways of the world.

Cathy Myers and Gina White, for all your help and talks we've had over the past two years. You've both taught me a lot about life.

Katherine Gottschalk, for letting me use your internet after the IT department took ours away. Thanks for all your help and good luck in your future. 


\section{TABLE OF CONTENTS}

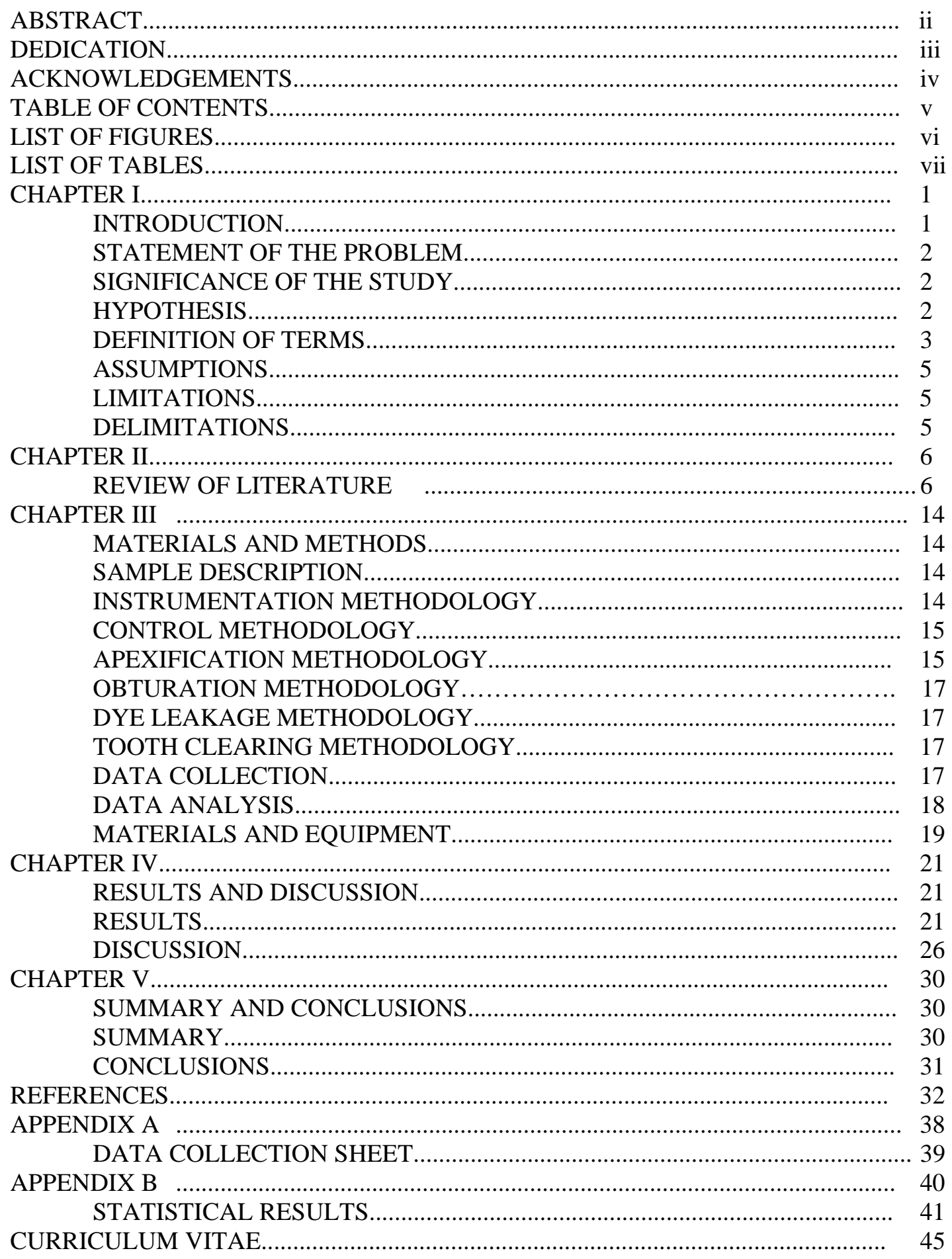




\section{LIST OF FIGURES}

Figure 1. Graph of Mean Apical Leakage............................ 23

Figure 2. Graph of Teeth Allowing Full-Length Leakage............ 24

Figure 3. Cleared tooth with MTA apical barrier exhibiting no leakage... 25

Figure 4. Cleared tooth with MTA apical barrier exhibiting full leakage...25 


\section{LIST OF TABLES}

Table 1. Research Design....................................... 15

Table 2. Mean Leakage and Standard Deviation..................... 22

Table 3. Teeth Allowing Full-Length Leakage..................... 22 


\section{CHAPTER I INTRODUCTION}

It is quite common in childhood that humans suffer damaging blows to their dentition resulting in the need for root canal therapy. This situation is complicated when the root apex is open and conventional root canal therapy is not a valid treatment option. Endodontic treatment of the pulpless tooth with an immature root apex poses a special challenge for the clinician. Historically, the treatment of choice for such situations was debridement of the root canal space and application of a calcium hydroxide paste in an attempt at apexification; however this historic treatment has many drawbacks including poor patient compliance and possible damage to root dentin. The main difficulty encountered is the lack of an apical stop against which to compact an interim dressing of calcium hydroxide $\left(\mathrm{Ca}(\mathrm{OH})_{2}\right)$, or the final obturation material. In these situations the unpredictability of the result, the difficulty in creating a leak-proof temporary restoration for the duration of treatment, and the difficulty in protecting the thin root from fracture may lead to complications when using traditional $\left(\mathrm{Ca}(\mathrm{OH})_{2}\right.$-based $)$ apexification techniques. Furthermore, given the increased mobility of today's society, lengthy treatment protocols are fraught with problems, and may not be followed through to completion. This may lead to ultimate failure of the case. Mineral Trioxide Aggregate (MTA) has recently been introduced for use in endodontics. Current literature supports its efficacy in a multitude of procedures including apexification. One-visit apexification may shorten the treatment time between the patient's first appointment and the final restoration 


\section{STATEMENT OF THE PROBLEM}

Is the seal of an immature tooth filled apically with an MTA plug affected by allowing differences in setting time prior to a back fill of gutta percha?

\section{SIGNIFICANCE OF THE STUDY}

The new method of MTA apexification has eliminated the need for recall over an extended period of time and has addressed the need for an apical seal. The drawback comes with the setting time of the material. Manufacturers recommend waiting at least 24 hours until placing a backfill of gutta percha over the material. This requires both the patient and practitioner to set extra appointments which may be unnecessary. Currently there are no studies which show dye leakage in apexification cases with MTA as a result of setting time. This study will compare the apical leakage of an MTA barrier at varying setting times. The results could indicate the optimal time to place a backfill of gutta percha used in conjunction with the current technique for creating an apical seal in a blunderbuss canal.

\section{HYPOTHESIS}

There is no statistically significant difference in the apical leakage of underdeveloped roots sealed apically with a mineral trioxide aggregate plug whether they are obturated immediately with gutta percha or subsequently at later appointments. 


\section{DEFINITION OF TERMS}

Open apex - a root end configuration in which the apical constriction is greater than one millimeter determined either radiographically or by direct visualization (in-vitro).

Blunderbuss apex - a root end configuration in which the apex is open and the root end is divergent.

Calcium hydroxide apexification - a process by which calcium hydroxide is used to aid in the production of a closed apex over a period of time ranging from 6 to 24 months.

Backfill - a process by which gutta percha and sealer are placed to completely fill the remaining canal space when an apical barrier is present.

Apical barrier - a process by which a material is placed to seal the open apex allowing a decrease in treatment time and earlier restoration.

Dye Leakage - a method of evaluating the penetration of liquids through a medium.

One-Step Apexification - obturation of a canal immediately after placement of an apical barrier.

Two-Step Apexification - obturation of a canal after allowing the apical barrier to set, most often after at least 24 hours.

Orthograde MTA placement - a process by which Mineral Trioxide Aggregate is placed into a canal from the coronal orifice.

$\underline{\text { MTA }}$ - Mineral Trioxide Aggregate - a relatively new material having similar properties and composition as Portland cement.

GMTA- Gray Mineral Trioxide Aggregate - The original form of MTA marketed as MTA until 2002. The major difference between GMTA and MTA (white) is the concentrations of $\mathrm{Al}_{2} \mathrm{O}_{3}, \mathrm{MgO}$, and $\mathrm{FeO}$.

$\underline{\text { Sealer }}$ - a material used in conjunction with an obturating material to provide a fluidtight barrier.

Immature tooth - a tooth in which the apical region appears open or blunderbuss.

Sodium hypochlorite - $\mathrm{NaOCl}$ (5.25\%) - an endodontic irrigant which provides antimicrobial action, lubrication during instrumentation, and dissolves both vital and necrotic tissue. 
EDTA - ethylenediaminetetraacetic acid (17\%) - an endodontic irrigant which serves as a chelating agent to remove inorganic debris (smear layer) and prepare the canal for obturation. 


\section{ASSUMPTIONS}

(1) Immature or open root apices cannot be endodontically treated without an apexification procedure. (2) The results of the calcium hydroxide apexification procedure can be unfavorable. (3) Instrumenting extracted teeth both coronally and apically will reproduce the anatomy of a blunderbuss canal. (4) Apical leakage is a good estimate of success/failure in the apical barrier technique.

\section{LIMITATIONS}

(1) This in-vitro study attempted to simulate the clinical conditions present when treating a blunderbuss canal (i.e. open apex and lack of matrix for condensation); however, results may vary from true in-vivo conditions. (2) The leakage of methylene blue dye was used to simulate leakage in the apical environment. This has been shown in numerous studies to not be a true measurement of leakage. (3) MTA was allowed to set for a predetermined amount of time prior to placing in methylene blue dye. In an in-vivo environment, leakage occurs immediately upon placement.

\section{DELIMITATIONS}

(1) Only single canal teeth were used. (2) Each tooth was instrumented coronally and apically in the same manner to produce a single apical opening and remove apical ramifications. 


\section{CHAPTER II REVIEW OF LITERATURE}

Both the classic and one-step MTA apexification methods rely on the use of calcium hydroxide after initial instrumentation and debridement. The idea to use calcium hydroxide for apexification procedures was originally utilized because of its high alkalinity and antibacterial properties (Frank 1966). Calcium hydroxide has also been shown to have some ability to dissolve necrotic tissue (Foreman and Barnes, 1990). The induction of apical closure after placement of calcium hydroxide is believed to occur because of its actions on bacterial cytoplasmic membranes, proteins, and DNA (Farhad and Mohammadi, 2005). Despite its high pH, calcium hydroxide has a slight demineralizing effect on dentin and has been shown to cause the release of TGF-beta. This and other growth factors stimulate and accelerate reparative dentinogenesis. (Smith, et al., 1995).

Although it may seem like the ideal material to treat a case with a blunderbuss apex, calcium hydroxide alone comes with several major drawbacks. One example is the time required for treatment. Kleier and Barr (1991) determined that the usual time required for apexification ranged from 6 to 24 months with an average of 1 year \pm 7 months. Another drawback comes with the need for frequent recall appointments to follow progression of the case (Farhad and Mohammadi, 2005). In addition, Andreasen et al. (2002) have shown that exposure of immature roots to calcium hydroxide for more than one year can weaken the root structure. This could have grim effects on the longevity of a permanent restoration following treatment. 
Mineral trioxide aggregate (MTA) was first described in the dental scientific literature by Lee, et al. (1993), and was given approval for endodontic use by the FDA in 1998 (Schmitt D, et al., 2001). It has been recently utilized in endodontics in several procedures, including: pulp capping, perforation repairs, apical barriers in open apices, and as root-end filling materials (Torabinejad and Chivian, 1999). MTA is a modified type of Portland cement and is composed primarily of calcium, aluminum, silicates, bismuth and oxygen (Camilleri, et al., 2005). Portland Cement and MTA are not identical materials. MTA products have been reported to have a smaller mean particle size, contain fewer toxic heavy metals, has a longer working time, and appears to have undergone additional processing/purification than regular Portland cements. (Abdullah, et al, 2002 and Islam,et al, 2006). Sarkar, et al. (2005) studied the basis for the properties of MTA. They concluded that calcium is released from MTA and reacts with phosphates in the tissue fluid to form hydroxyapatite. Until 2002 only one MTA consisting of graycolored powder was available, and in that year white MTA was introduced as ProRoot MTA for esthetic reasons. The major difference between gray MTA and white MTA is the concentrations of $\mathrm{Al}_{2} \mathrm{O}_{3}, \mathrm{MgO}$, and $\mathrm{FeO}$ (Asgary S et al., 2005).

MTA, like any new material, has been tested numerous times for potential effects on host tissues. Ribeiro, et al. (2006), found that MTA was not a genotoxin, nor did it produce cellular death using a Chinese hamster ovary cell model. In another study, Ribeiro, et. al (2006) found very similar results, suggesting MTA and Portland Cement are not genotoxins and are not able to induce cellular death. In 2005, Camilleri, et al. found biocompatibility testing of the cement failed to find presence of toxic leachables in 
gray or white MTA. In addition, they found the addition of bismuth oxide did not interfere with biocompatibility.

Important to any material used in endodontics is the response of the periodontal ligament cells as well as the bone-forming osteoblast. Balto (2004) used a scanning electron microscope study to determine that set-MTA was inviting to fibroblasts, noting that the cells were round, displayed smooth surfaces, and were tightly attached. Keiser, et. al (2000) found MTA to be less toxic to human periodontal ligament fibroblasts when compared to amalgam and SuperEBA, supporting the use of MTA in the periapical environment. Pistorius, et al. (2003) showed that fibroblasts have a significant decrease in protein production when in contact with amalgam; however, MTA and titanium had little effect on protein synthesis. They also found that while amalgam caused a significant reduction in cell proliferation, MTA and titanium only slightly influenced this parameter. Pelliccioni, et al. (2004) used osteoblast-like cells to study cell response to MTA. They found the cells attached to the rough surface and spread. In addition, the cells were viable, grew, and released collagen at 72 hours. Mitchell, et al. (1999) also found a positive response of osteoblasts to MTA and declared MTA biocompatible and suitable for clinical trials. Zhu, et al. (2000) showed that osteoblasts attached and spread on MTA and composite, but did not spread on amalgam.

Animal studies on host response to MTA have confirmed the cellular response. Saidon, et al. (2003) found bone healing and minimal inflammatory response in a surgical model that involved implanting MTA into a bone cavity aseptically created in male guinea pigs. Baek, et al. (2005) compared the response of periapical tissues in dogs to 
MTA, SuperEBA, and amalgam. They found MTA to have the most favorable periapical response, with formation of new cementum over the MTA.

Another claimed advantage of MTA is its antimicrobial activity. Sipert, et al. (2005) found MTA to inhibit the growth of Enterococcus faecalis, Micrococcus luteus, Staphylococcus aureus, Staphylococcus epidermidis, Pseudomonas aeruginosa, and Candida albicans, while only allowing growth of Escherichia coli. Al-Nazhan and AlJudai (2003) also found MTA to be effective in killing C. albicans. In addition, AlHezaimi, et al. (2005) concluded that MTA in the concentration of $50 \mathrm{mg} / \mathrm{ml}$ is effective in killing C. albicans. Hachmeister, et al. (2002) showed that when used in the treatment of immature apices, MTA provides resistance to bacterial penetration by E. faecalis and S. epidermis but not Enterobacter aerogenes. de Leimburg, et al. (2004) reported similar resistance to E. faecalis penetration after 10 days in teeth with immature apices. GMTA was also evaluated against Actinomyces viscosus microleakage for up to 70 days in simulated immature apices that had received a 5mm apical filling (Al-Kahtani, et al., 2005).

Some bonding ability between MTA and dentin exists, though it is quite less than that seen between dentin and resin. Yan, et al. (2006) examined the effects of sodium hypochlorite, chlorhexidine, and Glyde file prep on the MTA-dentin bond. Their results showed that while sodium hypochlorite and chlorhexidine had little effect, the bond strength was greatly decreased by the Glyde file prep.

Many studies have evaluated the efficacy of MTA as a root end filling material to be used during apical surgery. A major concern for any root end filling is the ability of the material to adapt to the dentinal walls. Gondim, et al. (2003) compared SuperEBA, 
IRM, and MTA and found the marginal adaptation of MTA to be good both with and without finishing procedures. In 1995, Torabinejad, et al. found MTA to have better adaptation compared to amalgam, SuperEBA, and IRM while using a scanning electron microscope study. Xavier, et al. (2005) demonstrated that MTA had superior marginal adaptation when compared to SuperEBA and Vitremer. Finally, when comparing amalgam and MTA, Shipper, et al. (2004) showed superior adaptation of MTA with smaller gap production.

At the present time, no prospective studies using MTA materials for apexification and/or apexogenesis procedures have been reported. However, successful individual case reports do exist (Karabucak, et al (2005), Giuliani V, et al (2002), Maroto M, et al. (2003), Hayashi M, et al. (2004). According to Kratchman (2004), the technique of onestep apexification offers an alternative to draw-out cases with several medicamentchanging appointments that often result in a failed attempt at root-end closure. With the favorable histologic response of MTA, this material is the best current choice for this procedure. Completion of these cases in an effective and efficient way allows for permanent restorations to be done in a timelier manner, prolonging the longevity of these teeth.

The ideal setting time of MTA obturations has been shown to be related to the presence of a humid environment for an extended period. MTA powder is mixed with supplied sterile water in a 3:1 powder/liquid ratio. It is recommended that a moist cotton pellet be temporarily placed in direct contact with the material and left until a follow-up appointment. Upon hydration, MTA materials form a colloidal gel that solidifies to a hard structure in approximately 3-4h. ( Dammascheke T, et al., 2005 and Torabinejad M, 
et al., 1995). Gancedo-Caravia L, et al. (2006) showed that humidity significantly increased the push-out strength of MTA obturations. The effect of curing time depended on humidity: while in the absence of humidity the push-out strength did not increase after 3 days, in the presence of humidity a lengthening of the curing time up to 21 days produced a moderate increase over and above the large initial increase obtained in the first 3 days. Lee YL, et al. (2004) showed that MTA microhardness and setting is adversely affected with exposure to the $\mathrm{pH}$ range of inflammatory environments (low $\mathrm{pH}$ ) as compared to physiologic conditions (pH 7). Sluyk SR, et al. (1998) showed that there is some evidence that MTA materials possess a prolonged maturation process that continues past the stated setting time of 3-4 hours. They showed that MTA reaches maximum push-out strength at 21 days and is greater at $72 \mathrm{~h}$ compared to $24 \mathrm{~h}$. Matt, et al. (2004) showed that the two-step technique showed significantly less leakage than onestep. In a study done by Barrieshi-Nusair, et al.(2006), MTA was used as a pulpotomy material in 31 vital cariously exposed teeth and immediately restored without an interim placement of a moist cotton pellet. At two years 79\% remained vital and asymptomatic.

Leakage studies are also important in the evaluation of the use of MTA in the apical environment. Torabinejad, et al. (1993) in a dye leakage study showed that MTA leaked significantly less than both amalgam and SuperEBA. Islam, et al. (2005) compared the sealing efficacy of MTA and regular Portland cement and found that neither allowed any microleakage. In addition, MTA was shown to produce a superior seal against endotoxin at twelve weeks when compared with SuperEBA, IRM, and amalgam (Tang, et al., 2002). 
Some authors were concerned that the thickness of the MTA filling placed may be important in the seal produced. Valois and Costa (2004) compared leakage in teeth filled at $1,2,3$, and $4 \mathrm{~mm}$ depths. They found the four millimeter thickness to be significantly more effective at preventing leakage of a protein-dye complex.

Hachmeister, et al. (2002) found leakage in all of their MTA apical barriers at day 70; however, they concluded that a four millimeter thickness of MTA had better resistance to displacement. The authors attributed the universal leakage to the current method of orthograde placement stating, "it was the intracanal delivery technique and not the MTA that contributed to leakage observed in this study.” They also demonstrated that placement of calcium hydroxide for one week had no effect on the leakage or displacement of the MTA barrier. Martin, et al. (2007) concluded that a 3-5mm thick MTA orthograde apical plug for one-visit apexification produces a reasonable seal that improves over time. In studying bacterial leakage, de Leimburg, et al. (2004) found no difference in observable leakage whether the barrier be one, two, or three millimeters thick. An adequate seal was produced at all thicknesses. In 2004, Matt, et al. found a five millimeter barrier of MTA to have superior seal compared to a two millimeter thickness regardless of the type of MTA or the number of steps used in placement. AlKahtani, et al. (2005) used an in-vitro model to demonstrate the seal of a five millimeter MTA apical barrier is superior to a two millimeter barrier.

Another major issue when describing MTA placed orthograde as an apical barrier is the method of delivery. Given the shape of the blunderbuss canal, there is no matrix to condense the MTA against, making this situation quite different from that seen during apical surgery. Lawley, et al. (2004) compared the placement of an apical MTA barrier 
both ultrasonically and non-ultrasonically. At 45 days, their results indicated a significantly better seal of the ultrasonically placed MTA; however, by 90 days no significant difference existed. Aminoshariae, et al. (2003) compared hand condensation and ultrasonic condensation of the apical MTA barrier. After examining the specimen both radiographically and microscopically, the authors suggested that hand condensation resulted in better adaptation and less formation of voids. 


\section{CHAPTER III \\ MATERIALS AND METHODS}

\section{SAMPLE DESCRIPTION}

One hundred twenty, single-rooted, extracted teeth were collected from the Oral \& Maxillofacial Surgery Department at West Virginia University School of Dentistry and stored in sterile isotonic saline for a maximum of 120 days. The teeth were examined with a Global dental operating microscope at 20x for fractures and the presence of multiple foramina. Teeth with fractures or more than one visible foramen were discarded and replaced appropriately.

\section{INSTRUMENTATION METHODOLOGY}

A standard instrumentation procedure was carried out on every tooth. Standard access preparation was performed using a \#4 round bur, EndoZ bur, and the orifice located with an endodontic explorer. An ISO \#10 K-Type hand file was introduced into the canal and advanced to the apex to insure canal patency. The apical three millimeters of the root was then resected to eliminate apical ramifications and to relocate the apical opening to the center of the root structure. The ISO \#10 file was reintroduced and advanced until visible at the root end. When the tip of the file became visible at the terminus of the canal, the stopper was set to the reference point and measured.

After obtaining working length, the coronal portion of the canal was flared with Gates Glidden burs \#2, \#3, and \#4. Brasseler EndoSequence sized 0.06 tapered rotary files were advanced to the working length to size \#40. The same rotary instrument was then inserted in the apical foramen and advanced until D16 was even with the resected root-end. This created an apical opening with a diameter of $1.36 \mathrm{~mm}$. Irrigation with at 
least $5.0 \mathrm{ml}$ of $5.25 \%$ sodium hypochlorite was used to flush debris from the canal between each Gates Glidden bur and rotary file insertion. In order to simulate typical clinical procedures, after instrumentation each root was filled with calcium hydroxide paste using a 0.014 "capillary tip and stored in a $100 \%$ humid environment for one week. The paste was removed using a \#60 ISO hand file and copious irrigation with $3 \%$ sodium hypochlorite until no paste was visible. Each tooth was then randomly assigned to a test group as described in table 1.

Table 1. Research Design

\begin{tabular}{|l|l|l|l|l|l|l|}
\hline $\begin{array}{l}\text { Setting } \\
\text { Time of } \\
\text { MTA }\end{array}$ & None & 1 Hour & 4 Hours & 24 Hours & 1 Week & $\begin{array}{l}\text { Controls } \\
\text { (positive } \\
\text { and } \\
\text { negative) }\end{array}$ \\
\hline $\begin{array}{l}\text { Number } \\
\text { of teeth }\end{array}$ & 20 & 20 & 20 & 20 & 20 & $10+10$ \\
\hline
\end{tabular}

\section{CONTROL METHODOLOGY}

Positive and negative controls were treated as described in the following sections with these exceptions:

1. The entire canal of the positive control group was filled with zinc phosphate cement, and did not receive an MTA apical barrier or gutta-percha.

2. The entire root, including the apical end, was painted with nail varnish in the negative control group.

\section{APEXIFICATION METHODOLOGY}

Each tooth was inserted in a one inch square of flower arrangement foam which had been soaking in tap water for five minutes. A \#8 $1 \frac{1}{2} \mathrm{P}$ Schilder plugger was advanced to 
working length to ensure none of the foam had entered the canal on insertion. The tooth was dried with \#80 paper points placed $1.0 \mathrm{~mm}$ short of working length (advancing to full length caused wicking of moisture from the foam) until the points were visibly dry.

The canals was soaked and irrigated with a 3.0cc final rinse of 5.25\% NaOCl.

The canals were then dried with \#80 paper points placed $1.0 \mathrm{~mm}$ short of the apex until the points were visibly dry.

A \#9P Schilder plugger was fitted in each canal and a stopper placed $1.0 \mathrm{~mm}$ short of working length. MTA was mixed with MTA water as per the manufacturer's directions. The freshly mixed MTA was delivered to the access preparation with a micro carrier. The MTA was advanced down the coronal portion of the canal with a \#11P Schilder plugger and then teased to the apex with the previously fitted \#9 Schilder plugger. A \#80 paper point was used to tamp the MTA to place, move excess MTA left along the walls towards the apex, and to remove excess moisture. This method of placement was repeated until a $5.0 \mathrm{~mm}$ apical plug was obtained. If the length of the plug exceeded $5.0 \mathrm{~mm}$ an ISO \#60 hand file was used to remove excess MTA. A radiograph was made to assess the density of the apical barrier. If a void was detected, the MTA was removed with an ISO \#60 hand file and the apexification procedure was repeated.

A moist cotton pellet was placed in the coronal aspect of the canal and a temporary restorative material (Cavit) used to seal the access (with the exception of the immediate obturation group). The tooth was then placed in an environment of $100 \%$ humidity for differing amounts of time, according to the specific group each tooth was assigned, to allow the MTA to set. 


\section{OBTURATION METHODOLOGY}

Cavit was removed from the access with a round bur and the cotton pellet removed with a barbed broach. Each canal was irrigated with 3.0cc of 17\% EDTA and 3.0cc of 5.25\% $\mathrm{NaOCl}$ and dried with a \#70 paper point. Roth’s 801 Elite grade sealer was placed in each canal with a lentulo spiral, followed by gutta-percha using the Obtura II. Excess gutta-percha was removed to the level of the canal orifice using a System B plugger and condensed with a \#9 Schilder plugger. Cavit was placed in the access.

\section{DYE LEAKAGE METHODOLOGY}

Red finger nail polish was used to cover the entire tooth except the apical opening of the resected root end to prevent dye leakage through lateral canals and dentinal tubules and to improve the coronal seal. Each tooth was then submerged in $1 \%$ methylene blue dye for 48 hours, after which the nail varnish was removed with acetone.

\section{TOOTH CLEARING METHODOLOGY}

Each tooth was placed in 5\% nitric acid for 72 hours. The acid was changed at 24 and 48 hours and agitated by hand three times every 24 hours. The tooth was rinsed under running tap water for one hour and then dehydrated for 24 hours in reagent alcohol (90\% ethyl alcohol; 5\% methyl alcohol; 5\% isopropyl alcohol). The alcohol was poured off and the tooth covered in synthetic methyl salicylate (2-hydroxybenzoate methyl ester; $\mathrm{C}_{8} \mathrm{H}_{8} \mathrm{O}_{3}$ ) for three hours to complete the clearing process.

\section{DATA COLLECTION}

After clearing the teeth, the methylene blue dye that had entered through the apex was readily visible. The extent of the leakage was evaluated with a measuring microscope to the nearest tenth of a millimeter. The measurement was made from the 
resected root-end to the coronal most extent of the leakage. If the leakage was greater than the full length of the MTA apical plug, the measurement was stopped at the coronal most point of the plug.

\section{DATA ANALYSIS}

A one-way ANOVA was used to determine if a significant difference existed between groups and Tukey's HSD test used to identify which groups were significantly different. Significance was determined at $\mathrm{P}<0.05$. Statistical analysis could not be completed on samples exhibiting full length leakage. A Chi-Square test would be required, but at least five samples showing full-length leakage in each group would have been needed. 


\section{MATERIALS AND EQUIPMENT}

- \#9P, 11P Schilder pluggers (Caulk Dental, Milford DE)

- Absorbent paper points \#70 (Dentsply Maillefer, Tulsa OK)

- Acetone (Fisher Scientific, Fair Lawn, NJ)

- Capillary Tips (Ultradent Products, South Jordan UT)

- Cavit (3M ESPE, St. Paul, MN)

- Clorox (The Clorox Company, Oakland CA)

- Cotton forceps (Hu-Friedy, Chicago IL)

- Cover Girl Nail Polish (Procter \& Gamble, Cincinnati, OH)

- Deluxe Floral Foam (Smithers-Oasis Company, Cuyahoga Falls, OH)

- Dentsply/Tulsa Dental Electric rotary motor and handpiece (Tulsa Dental, Tulsa OK)

- EDTA solution, $17 \%$ (Pulpdent Corporation, Watertown MA)

- EndoSequence 0.06 rotary files (Brasseler USA, Savannah, GA)

- Flexofile ISO endodontic files (Dentsply Maillefer, Tulsa OK)

- Gaertner measuring microscope (Gaertner Scientific Corporation, Chigaco IL)

- Gates Glidden burs \#2-4 (Dentsply Maillefer, Tulsa OK)

- Global operating microscope (Global Surgical Corporation, St. Louis, MO)

- Hy-Bond Zinc Phosphate Cement (ShoFu Inc, Kyoto, Japan)

- Max-i-Probe endodontic irrigating probes (Dentsply Rinn, Eglin, IL) 
- Methyl Salicylate ( Sigma-Aldrich Inc, St. Louis, MO)

- Methylene Blue Dye, 1\% (VWR Scientific Products, West Chester, PA)

- Micro carrier (CK Dental Specialties, Ortonville, MI)

- Nitric Acid (VWR Scientific Products, West Chester, PA)

- Obtura II (Obtura Spartan, Fenton, MO)

- Periapical dental film (Eastman Kodak, Rochester, NY)

- ProRoot MTA (Tulsa Dental, Tulsa OK)

- Pulpdent Paste - $\mathrm{Ca}(\mathrm{OH})_{2}$ (Pulpdent Corporation, Watertown MA)

- Reagent Alcohol (Fisher Scientific, Fair Lawn, NJ)

- Roth Root Canal Cement (Roth International, Chicago, IL) 


\section{CHAPTER IV RESULTS AND DISCUSSION}

\section{RESULTS}

The statistical analysis of the data was performed with a one-way ANOVA and Tukey's HSD tests. Dye penetrated the entire length of the positive controls, and there was no dye penetration in negative controls. The results of this study did not support the null hypothesis. The results indicated that significantly more leakage was seen in the immediate placement and 1 hour setting time groups than in the 4 hour, 24 hour, and 1 week setting time groups $(\mathrm{p}<0.0001)$. While the immediate placement group exhibited more leakage than the 1 hour setting time group, the difference was not significantly

different. In addition, the difference in leakage between the 4 hour, 24 hour, and 1 week setting time was not significantly different.

Full length leakage occurred in all groups except the 1 week setting time group. This occurred more in the immediate placed and 1 hour set time groups.

Positive and negative controls behaved as expected. Table 2 shows the mean leakage and standard deviation; Table 3 indicates the number of teeth in each group allowing leakage greater than the length of the plug. 
Table 2. Mean Leakage in $\mathrm{mm}$ and Standard Deviation

\begin{tabular}{|c|c|c|c|c|c|}
\hline $\begin{array}{c}\text { Setting } \\
\text { time of } \\
\text { MTA }\end{array}$ & None & $1 \mathrm{Hr}$ & $4 \mathrm{Hrs}$ & $24 \mathrm{Hrs}$ & $\begin{array}{c}168 \mathrm{Hrs} \\
(1 \mathrm{Week})\end{array}$ \\
\hline $\begin{array}{c}\text { Mean } \\
\text { leakage } \pm \\
\text { SD }\end{array}$ & $4.2 \pm 1.3$ & $3.8 \pm 1.3$ & $1.7 \pm 1.2$ & $\begin{array}{c}1.7 \pm \\
1.5\end{array}$ & $1.6 \pm 1.2$ \\
\hline
\end{tabular}

Table 3. Teeth Allowing Full-Length Leakage

\begin{tabular}{|c|c|c|c|c|c|}
\hline $\begin{array}{c}\text { Setting } \\
\text { time of } \\
\text { MTA }\end{array}$ & None & $1 \mathrm{Hr}$ & $4 \mathrm{Hr}$ & $24 \mathrm{Hr}$ & $\begin{array}{c}168 \mathrm{Hr} \\
(1 \mathrm{Week})\end{array}$ \\
\hline $\begin{array}{c}\text { Teeth } \\
\text { Allowing } \\
\text { Full-length } \\
\text { leakage }\end{array}$ & 7 & 4 & 1 & 1 & 0 \\
\hline
\end{tabular}


Figure 1. Mean Apical Leakage based on Setting Time

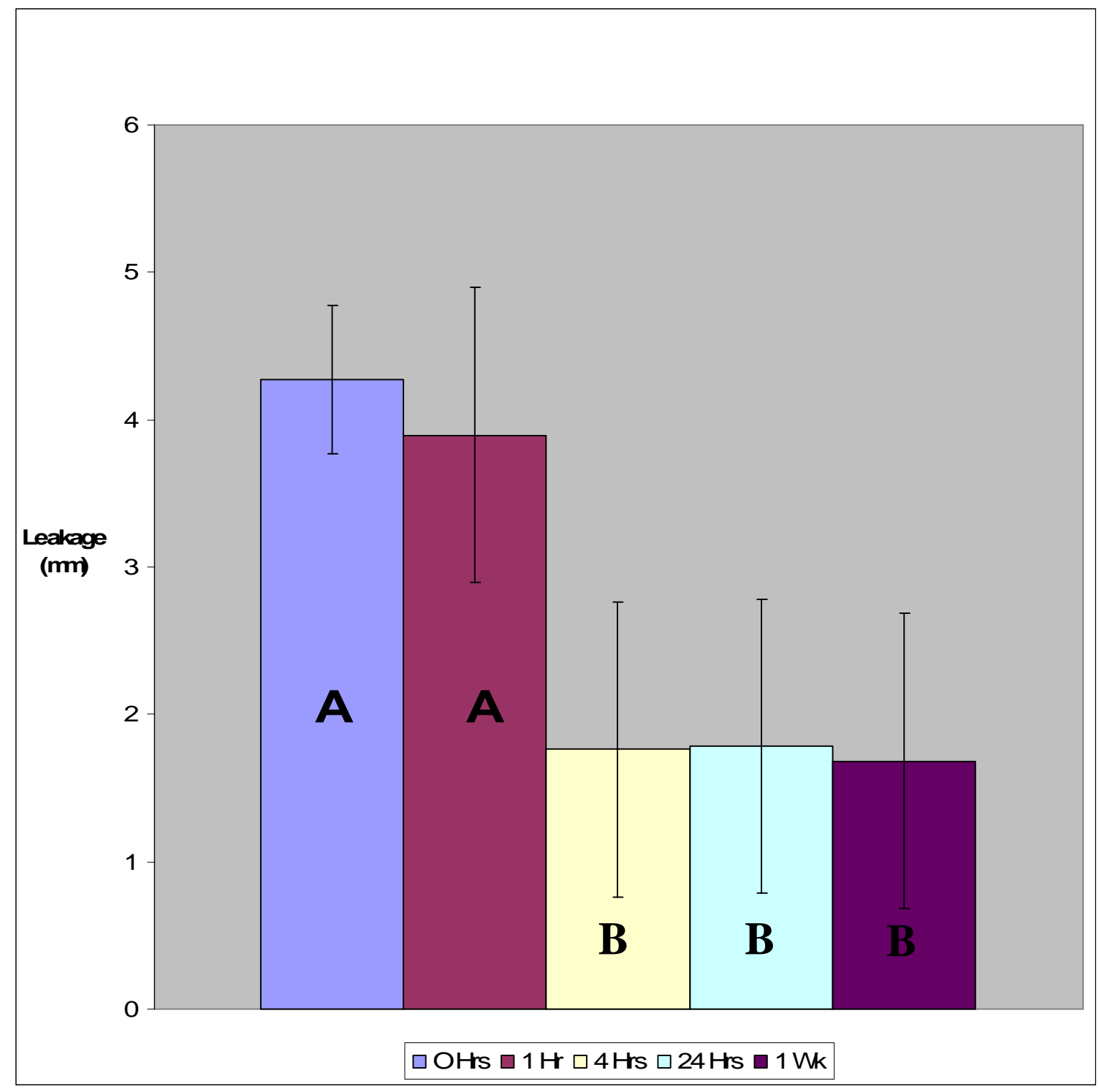

Bar with the same letter were not significantly different. Error Bar = One Standard Deviation 
Figure 2 Teeth Exhibiting Full Length Leakage ( $>5 \mathrm{~mm})$

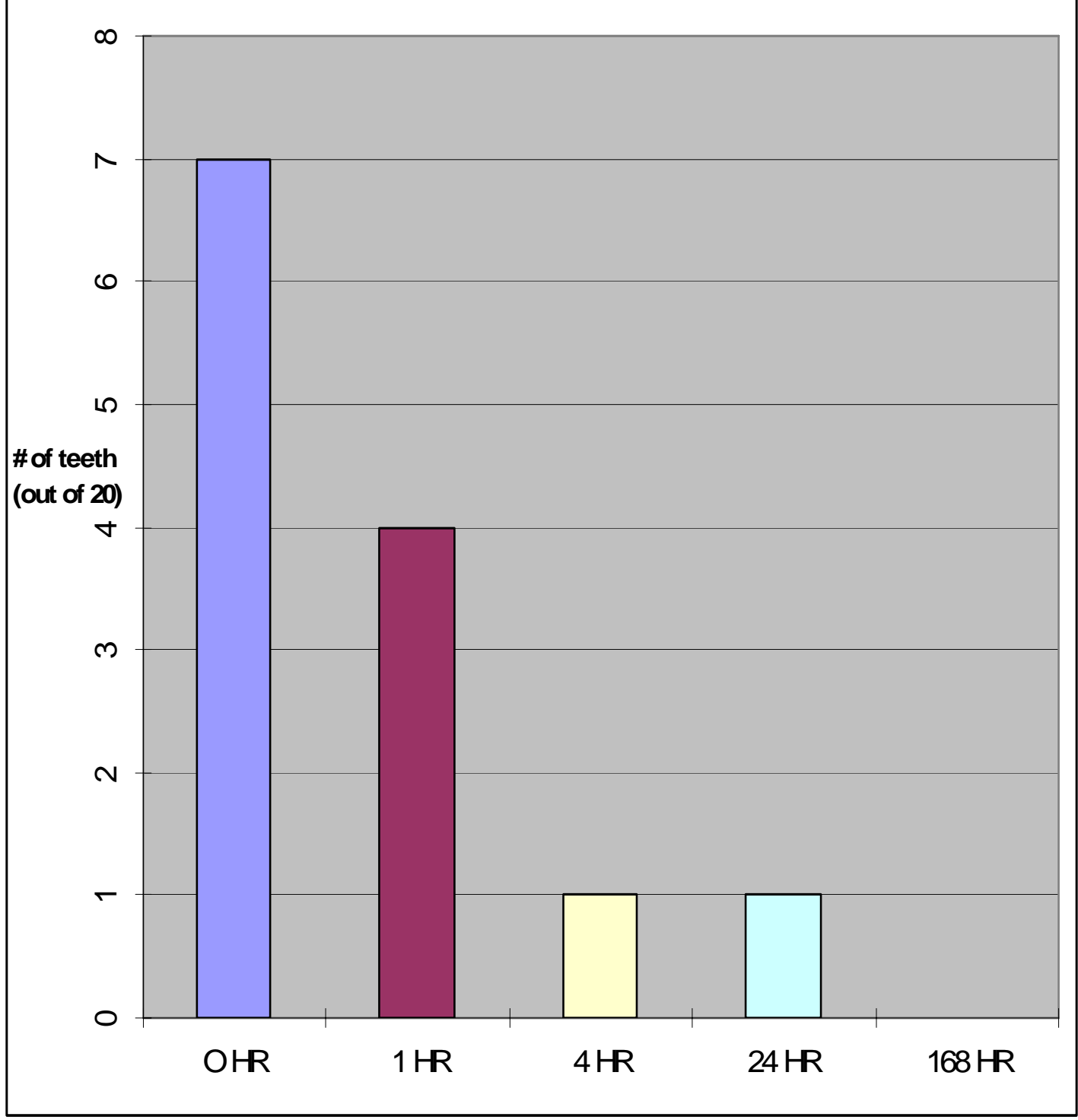


Figure 3. Cleared tooth with MTA apical barrier exhibiting no leakage.

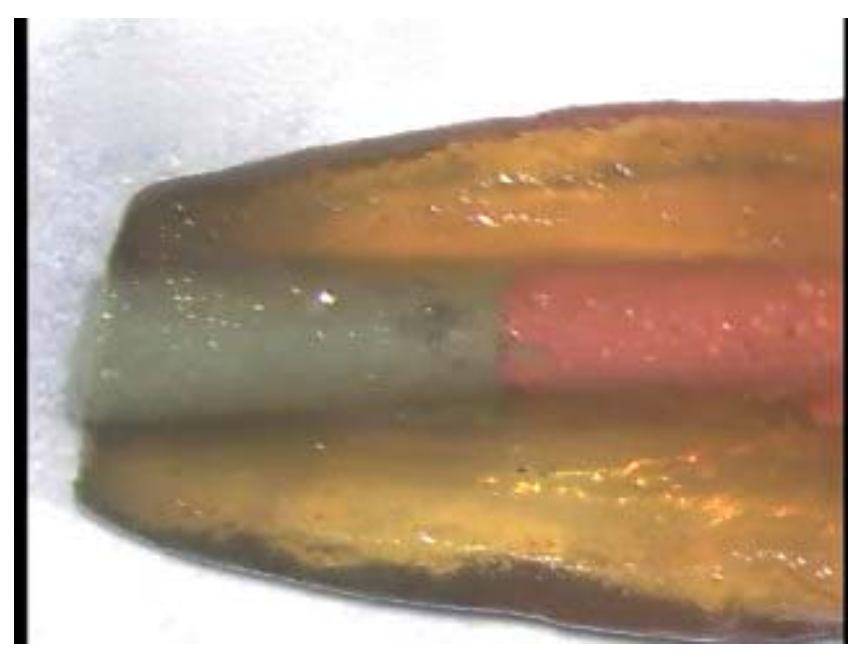

Figure 4. Cleared tooth with MTA apical barrier exhibiting full leakage.

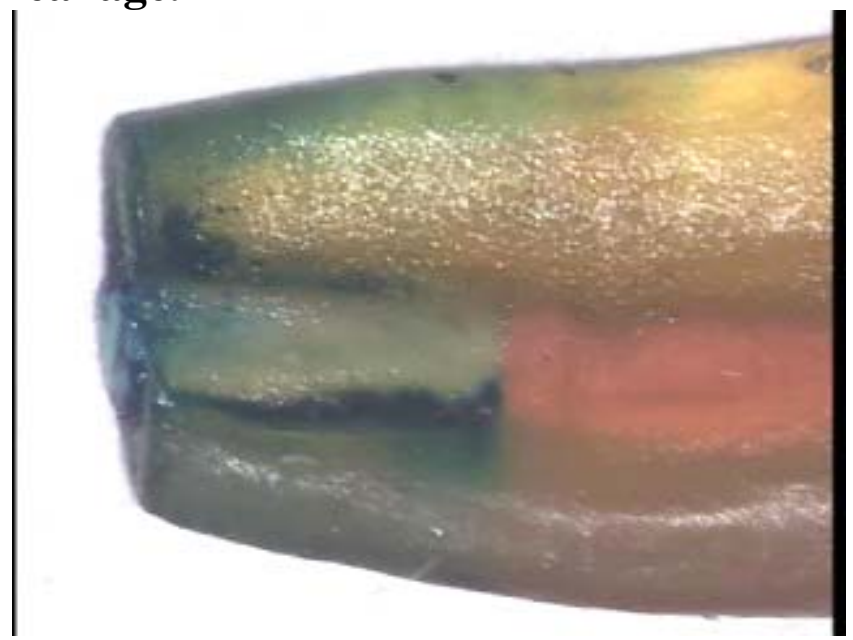




\section{DISCUSSION}

The literature is abounding with studies reporting the numerous advantages of MTA in endodontics. Despite the numerous favorable properties that support its clinical use, the main disadvantage of MTA is its prolonged setting time. According to Chng et al. (2005), it takes on average about 2 hours and 45 minutes for it to set enough before a restoration can be placed. Manufacturers claim that a cotton pellet should be placed over the setting MTA for 4 hours before placement of a final restoration. Hence, the patient has to be recalled for a second visit for completion of treatment. Kogan et al. (2006) reported that adding chlorhexidine gluconate, sodium hypochlorite, K-Y jelly, and $\mathrm{Ca}(\mathrm{Cl})_{2}$ to MTA to can reduce setting time. However, there was also a reduction in the

compressive strength. A study by Huang et al. (2008) reported that adding $\mathrm{Na}_{2} \mathrm{HPO}_{4}$ to MTA decreases the setting time to only 26 minutes and has no effect on compressive strength. Camilleri (2008) concluded that the setting time of Portland cement can be reduced by excluding the gypsum during the last stage of the manufacturing process without affecting its other properties.

Recent studies by Nandini et al. and Ballal et al. $(2007 ; 2008)$ have concluded that conventional glass ionomer cement can be layered over partially set MTA after 45 minutes of setting time. Both the MTA and glass ionomer continue to set uninhibited. This enables the clinician to place a permanent restoration over the conventional glass ionomer cement so as to make it a single visit procedure.

Witherspoon et al. (2001) suggested that a one-visit apexification procedure is possible. Matt et al. (2004) concluded that a two-step MTA placement technique showed 
significantly less apical leakage than a one-step procedure. Findings of this experiment clearly agree with this previous study and support the two-step technique over the onestep procedure. MTA powder consists of fine, hydrophilic particles that set in the presence of water. It is possible that moisture from the periapical environment could be sufficient for MTA to set, but is seems clear that additional moisture from a cotton pellet is crucial for the material to establish optimum properties.

Although the methods for mixing and placing the cement were well standardized in this study, Fridland et al. (2003) has shown that increased water-to-powder ratios could account for increased solubility and porosity of the material. It is likely that clinicians vary in the way they mix and place the cement.

A limiting factor in this in-vitro study is that it does not simulate a realistic clinical situation. Upon placement of an MTA barrier in-vivo, it begins to leak immediately with periapical fluids. The MTA does not have a chance to set prior to leakage. In this study, teeth were not placed into methelyne blue dye until the MTA had already set for a predetermined amount of time. To make this study more realistic, teeth would have to be exposed to methylene blue dye immediately after MTA placement and throughout the entire experiment. In a study done by Hachmeister, et al. (2002) it was found that leakage of all apical barriers occurs by 70 days. It was concluded that the delivery method contributed to leakage and not the MTA. This study also showed leakage in all samples.

Under the parameters of this study, it was shown that more leakage occurs when MTA is given no time to set or with only one hour of setting time. Although more leakage occurred on average with immediate obturation than with one hour of setting 
time, the difference was not significantly different. On average, about $4 \mathrm{~mm}$ of the MTA barrier was penetrated with methylene blue dye for these two groups. The other groups leaked on average about $1.7 \mathrm{~mm}$. The difference between the 4 hours, 24 hours, and 1 week groups was also not significantly different. When performing a two-step apexification procedure, the canal is irrigated with a disinfectant, such as sodium hypochlorite, prior to obturating the remainder of the canal. If leakage had occurred through the MTA barrier between appointments, this rinse would theoretically remove any contaminants that may result in a failure.

A two-step procedure may also be ideal to be sure that the apical barrier is strong enough to withstand the force of condensation during obturation. With a one-step procedure, the MTA may not be able to withstand excessive forces and may become forced out the apex.

Various methods have been developed to study the leakage associated with dental materials. The most common include: fluid filtration, bacterial test, electrochemical method, and dye penetration. Pommel, et al. (2001) showed that there is a lack of correlation among the four methods and that several studies are required before comparing the apical seal obtained with various filling techniques. Karagenc, et al. (2006) also noted the lack of correlation and determined that clinical significance of leakage tests in vitro is questionable. Camps, et al. (2003) compared the classical dyepenetration method to a dye-extraction method, with a fluid-filtration method as control. This study showed the limitation of the classical dye-penetration studies and that the dyeextraction method gave the same results as fluid filtration. According to $\mathrm{Wu}$, et al. (1993), significant decoloration occurs of 1\% methylene blue after 24 hours of contact 
with MTA-filled roots. In the study, he fails to describe what decoloration means or if it significantly effects the visibility of leakage. The teeth in this study were soaked in $1 \%$ methylene blue dye for 48 hours. If Wu's study is correct, this could have caused a color change in the dye and resulted in significant differences in the actual amount of leakage measured. As described by Monticelli, et al. (2007) a new model for performing fluid filtration leakage studies has been developed using a computerized device which performs automated data collection. This was developed after a modified designed previously reported by Pashley, et al. (1986). This experiment could be repeated using the fluid filtration or bacterial leakage models to compare results and make the study more clinically accurate.

Further studies should be done to test the difference in leakage between groups which have set at 1 hour, 2 hours, 3 hours, and 4 hours. This could be clinically relevant since a reduction in settimg time could save valuable time of both the patient and clinician. 


\section{CHAPTER V \\ SUMMARY AND CONCLUSIONS}

\section{SUMMARY}

The new method of MTA apexification has eliminated the need for recall over an extended period of time and has addressed the need for an apical seal. The drawback comes with the setting time of the material. Manufacturers recommend waiting at least 24 hours until placing a backfill of gutta percha over the material. The purpose of this study was to quantitatively compare the dye leakage of an MTA apical barrier after immediate placement, 1 hour, 4 hours, 24 hours, and 1 week of setting time.

It was hypothesized that no difference in the apical leakage of underdeveloped roots sealed apically with a mineral trioxide aggregate plug whether they are obturated immediately with gutta percha or subsequently at later appointments. The results of this in-vitro study did not support the null hypothesis. While samples allowed to set at least 4 hours or more did not differ significantly, the immediate placement group and 1 hour setting time group allowed significantly more leakage than those allowed to set at least 4 hours.

The manufacturers' recommendation of placing a moist cotton pellet in the canal, temporizing, and allowing the material to set for a minimum of 4 hours concurs with the findings of this in-vitro study. 


\section{CONCLUSIONS}

This in-vitro study using an extracted tooth model found that a setting time of at least four hours led to a superior seal of an MTA apical barrier when compared to a setting time of less than one hour. The samples allowed to set for more than four hours were not significantly different. 


\section{References}

Abdullah D, Pitt Ford TR, Papaioannou S, Nicholson J, McDonald F. An evaluation of accelerated Portland cement as a restorative material. Biomaterials 2002;23:4001-10.

Al-Kahtani, A., Shostad, S., Schifferle, R., \& Bhambhani, S. In-vitro evaluation of microleakage of an orthograde apical plug of mineral trioxide aggregate in permanent teeth with simulated immature apices. J Endod 2005;31:117-9.

Al-Nazhan, S. \& Al-Judai, A. Evaluation of antifungal activity of mineral trioxide aggregate. J Endod 2003;29:826-7.

Aminoshariae, A., Hartwell, G., \& Moon, P. Placement of mineral trioxide aggregate using two different techniques. J Endod 2003;29:679-82.

Andreasen, J., Farik, B., \& Munksgaard, E. Long-term calcium hydroxide as a root canal dressing may increase risk of root fracture. Dent Traumatol 2002;18:134-7.

Asgary S, Parirokh M, Egbbal MJ, Brink F. Chemical differences between white and gray mineral trioxide aggregate. J Endod 2005;31:101-3.

Baek, S., Plenk, H., \& Kim, S. Periapical tissue responses and cementum regeneration with amalgam, SuperEBA, and MTA as root-end filling materials. J Endod 2005;31:444-9.

Ballal, S., Venkateshbabu, N., Nandini, S., Kandaswamy, D. An in vitro study to assess the setting and surface crazing of conventional glass ionomer cement when layered over partially set mineral trioxide aggregate. J Endod 2008;34:478-480.

Balto, H. Attachment and morphological behavior of human periodontal ligament fibroblasts to mineral trioxide aggregate: a scanning electron microscope study. J Endod 2004;30:25-9.

Barrieshi-Nusair K, Qudeimat MA. A prospective clinical study of mineral trioxide aggregate for partial pulpotomy in cariously exposed permanent teeth. J Endod 2006;32:731-5.

Camilleri, J. The physical properties of accelerated Portland cement for endodontic use. Int Endod J 2008;41:151-157.

Camilleri, J., Montesin, F., Brady, K., Sweeney, R., Curtis, R., \& Ford, T. The constitution of mineral trioxide aggregate. Dent Mater 2005;21:297-303.

Camps J, Pashley D. Reliability of the dye penetration studies. J Endod: 2003;29:592-4. 
Chng HK, Islam I, Yap A., Tong YW., Koh E. Properties of a new root-end filling material. J Endod 2005;31:665-8.

Dammaschke T, Gerth HUV, Zuchner H, Schafer E. Chemical and physical surface and bulk material characterization of white ProRoot MTA and two Portland cements. Dent Mater 2005;21:731-8.

De Leimburg, M., Angeretti, A., Ceruti, P., Lendini, M., Pasqualini, D., \& Berutti, E. MTA obturation of pulpless teeth with open apices: bacterial leakage as detected by polymerase chain reaction assay. J Endod 2004;30:883-6.

Farhad, A. \& Mohammadi, Z. Calcium hydroxide: a review. Int Dent J 2005;55:293-301.

Foreman, P. \& Barnes, I. A review of calcium hydroxide. Int Endod J 1990;23:283-297.

Frank, A. Therapy for the divergent pulpless tooth by continued apical formation. J Am Dent Assoc 1966;72:87-93.

Fridland M, Rosado R. Mineral trioxide aggregate (MTA) solubility and porosity with different water-to-powder ratios. J Endod 2003;29:814-7.

Gondim, E., Zaia, A., Gomes, B., Ferraz, C., Teixeira, F., \& Souza-Filho, F. Investigation of the marginal adaptation of root-end filling materials in root-end cavities prepared with ultrasonic tips. Int Endod J 2003;36:491-9.

Giuliani V, Baccetti T, Pace R, Pagavino G. The use of MTA in teeth with necrotic pulps and open apices. Dent Traumatol 2002;18:217-21.

Hachmeister, D., Schindler, W., Walker, W., \& Thomas, D. The sealing ability and retention characteristics of mineral trioxide aggregate in a model of apexification. $\mathrm{J}$ Endod 2002;28:386-90.

Hayashi M, Shimizu A, Ebisu S. MTA for obturation of mandibular central incisors with open apices: case report. J Endod 2004;30:120-2.

Huang, T., Shie, M., Kao C., Ding, S. The effect of setting accelerator on properties of mineral trioxide aggregate. J Endod 2008;34:590-3.

Islam, I., Chng, H., Yap AUJ. Comparison of the physical and mechanical properties of MTA and Portland cement. J Endod 2006;32:193-7.

Islam, I., Chng, H., \& Yap, A. Comparison of the root-end sealing ability of MTA and Portland cement. Aust Endod J 2005;31:59-62. 
Karabucak B, Li D, Lim J, Iqbal M. Vital pulp therapy with mineral trioxide aggregate. Dent Traumatol 2005;21:240-3.

Karagenc B, Gencoglu N, Ersoy M, Cansever G, Kulekci G. A comparison of four different microleakage tests for assessment of leakage of root canal fillings. OOOOE 2006;102:110-3.

Keiser, K., Johnson, C., \& Tipton, D. Cytotoxicity of mineral trioxide aggregate using human periodontal ligament fibroblasts. J Endod 2000;39:288-91.

Kleier, D. \& Barr, E. A study of endodontically apexified teeth. Endod Dent Traumatol 1991;7:112-7.

Kogan P, He J, Glickman GN, Watanabe I. The effects of various additives on setting properties of MTA. J Endod 2006;32:569-72.

Kratchman, SI. Perforation repair and one-step apexification procedures. Dent Clin North Am 2004;48:291-307.

Kubo, C., Gomes, A., \& Mancini, M. In vitro evaluation of apical sealing in root apex treated with demineralization agents and retrofilled with mineral trioxide aggregate through marginal dye leakage. Braz Dent J 2005;16:187-91.

Lee YL, Lee BS, Lin FH, Lin AY Lan WH, Lin CP. Effects of physiological environments on the hydration behavior of mineral trioxide aggregate. Biomaterials 2004;25:787-93.

Lee SJ, Monsef M, Torabinejad M. Sealing ability of a mineral trioxide aggregate for repair of lateral root perforations. J Endod 1993;19:541-4.

Maroto M, Barberia E, Planells P, Vera V. Treatment of a non-vital immature incisor with mineral trioxide aggregate. Dent Traumatol 2003;19:165-9.

Martin, R., Monticelli, F., Brackett, W., Loushine, R., Rockman, R., Ferrari, M., Pashley, D., \& Tay, F. Sealing properties of Mineral Trioxide Aggregate Orthograde Apical Plugs and Root Fillings in an In Vitro Apexification Model. J Endod 2007;33:272-275.

Matt, G., Thorpe, J., Strother, J., \& McClanahan, S. Comparative study of white and gray mineral trioxide aggregate (MTA) simulating a one- or two-step apical barrier technique. J Endod 2004;30:876-9.

Monticelli F, Sword J, Martin RL, Schuster GS, Weller RN, Ferrari M, Pashley DH, Tay FR. Sealing properties of two contemporary single-cone obturation systems. Int Endod J 2007: 1-12. 
Mitchell, P., Pitt Ford, T., Torabinejad, M., \& McDonald, F. Osteoblast biocompatibility of mineral trioxide aggregate. Biomaterials 1999;20:167-73.

Nandini S, Ballal S, Kandaswamy D. Influence of glass-ionomer cement on the interface and setting reaction of mineral trioxide aggregate when used as a furcal repair material using laser raman spectroscopic analysis. J Endod 2007;33:167-72.

Pashley DH, Depew DD. Effects of the smear layer, Copalite, and oxalate on microleakage. Oper Dent 1986;11:95-102.

Pelliccioni, G., Ciapetti, G., Cenni, E., Granchi, D., Nanni, M., Pagani, S., \& Giunti, A. Evaluation of osteoblast-like cell response to ProRoot MTA (mineral trioxide aggregate) cement. J Mater Sci Mater Med 2004;15:167-73.

Pistorius, A., Willershausen, B., \& Briseno Marroquin, B. Effect of apical rootend filling materials on gingival fibroblasts. Int Endod J 2003;36:610-5.

Pommel, L., Jacqout, B., \& Camps, J. Lack of correlation among three methods for evaluation of apical leakage. J Endod 2001;27:347-50.

Roberts, HW., Toth, J., Berzins, DW., Charlton, D. Mineral trioxide aggregate material use in endodontic treatment: A review of the literature. Dent Mater 2008;24:149-164.

Ribeiro, D., Matsumoto, M., Duarte, M., Marques, M., \& Salvadori, D. Ex vivo biocompatibility tests of regular and white forms of mineral trioxide aggregate. Int Endod J 2006;39:26-30.

Ribeiro, D., Sugui, M., Matsumoto, M., Duarte, M., Marques, M., \& Salvadori, D. Genotoxicity and cytotoxicity of mineral trioxide aggregate and regular and white Portland cements on Chinese hamster ovary (CHO) cells in vitro. OOOOE 2006;101:258-61.

Saidon, J., He, J., Zhu, Q., Safavi, K, \& Spangberg, L. Cell and tissue reactions to mineral trioxide aggregate and Portland cement. OOOOE 2003;95:483-9.

Sarkar, N., Caicedo, R., Ritwik, P., Moiseyeva, R., \& Kawashima, I. Physicochemical basis of the biologic properties of mineral trioxide aggregate. J Endod 2005;31:97-100.

Schmitt D, Bogen G. Multifaceted use of ProRoot MTA root canal repair material. Pediatr Dent 2001;23:326-30.

Shipper, G., Grossman, E., Botha, A., \& Cleaton-Jones, P. Marginal adaptation of mineral trioxide aggregate (MTA) compared with amalgam as a root-end filling 
material: a low-vacuum (LV) versus high-vacuum (HV) SEM study. Int Endod J 2004;37:325-36.

Sipert, C., Hussne, R., Nishiyama, C., \& Torres, S. In vitro antimicrobial activity of Fill Canal, Sealapex, Mineral Trioxide Aggregate, Portland cement, and EndoRez. Int Endod J 2005;38:539-43.

Sluyk SR, Moon PC, Hartwell GR. Evaluation of setting properties and retention characteristics of mineral trioxide aggregate when used as a furcation perforation material. J Endod 1998;24:768-71.

Smith AJ, Garde C, Cassidy N, Ruch JV, Lesot H: Solubilization of dentin extracellular matrix by calcium hydroxide. J Dent Res 1995;74:829.

Tang, H., Torabinejad, M., \& Kettering, J. Leakage evaluation of root end filling materials using endotoxin. J Endod 2002;28:5-7.

Taylor, N. In-vitro Evaluation of Dye Leakage of a MTA Apical Barrier After Irrigation with 3.075\% Sodium Hypochlorite, 2\% Chlorhexidine, MTAD, or 17\% EDTA/3.075\% Sodium Hypochlorite. Unpublished Master's thesis. 2007. West Virginia University, Morgantown, West Virginia.

Torabinejad, M. \& Chivian, N. Clinical applications of mineral trioxide aggregate. J Endod 1999;25:197-205.

Torabinejad M, Hong CU, McDonald F, Pitt Ford TR. Physical and chemical properties of a new root-end filling material. J Endod 1995;21:349-53.

Torabinejad, M., Smith, P., Kettering, J., \& Pitt Ford, T. Comparative investigation of marginal adaptation of mineral trioxide aggregate and other commonly used root-end filling materials. J Endod 1995;21:295-9.

Torabinejad, M., Watson, T., \& Pitt Ford, T. Sealing ability of a mineral trioxide aggregate when used as a root end filling material. J Endod 1993;19:591-5.

Valois, C. \& Costa, E. Influence of the thickness of mineral trioxide aggregate on sealing ability of root-end fillings in vitro. OOOOE 2004;97:108-11.

Witherspoon DE, Ham K. One-visit apexification: technique for inducting rootend barrier formation in apical closures. Pract Proceed Aesthet Dent 2001;13:455-60.

Wu MK, Wesselink PR. Endodontic leakage studies reconsidered. Part I. Methodology, application and relevance. Int Endod J 1993;26:37-43.

Xavier, C., Weismann, R., de Oliveira, M., Demarco, F., \& Pozza, D. Root-end filling materials: apical microleakage and marginal adaptation. J Endod 2005;31:539-42. 
Yan, P., Peng, B., Fan, B., Fan, M., \& Bian, Z. The effects of sodium hypochlorite (5.25\%), chlorhexidine (2\%), and Glyde File Prep on the bond strength of

Zhu, Q., Haglund, R., Safavi, K., \& Spangberg, L. Adhesion of human osteoblasts on root-end filling materials. J Endod 2000;26:404-6. 
APPENDIX A

DATA SHEET 


\section{DATA COLLECTION SHEET}

\begin{tabular}{|c|c|c|c|c|c|}
\hline Group & $\mathrm{OHr}$ & $1 \mathrm{hr}$ & $4 \mathrm{Hr}$ & $24 \mathrm{Hr}$ & $1 \mathrm{Wk}$ \\
\hline 1 & 3.2 & 3.6 & 1.2 & 0.9 & 0.5 \\
\hline 2 & 4.8 & 2.8 & 0.6 & 0.1 & 1.0 \\
\hline 3 & 5.4 & 3.4 & 0.7 & 0.5 & 1.5 \\
\hline 4 & 4.2 & 5.0 & 5.0 & 1.1 & 4.5 \\
\hline 5 & 0.9 & 2.2 & 3.2 & 0.4 & 0.2 \\
\hline 6 & 2.4 & 4.5 & 1.2 & 1.3 & 0.9 \\
\hline 7 & 4.1 & 4.5 & 1.5 & 2.5 & 1.1 \\
\hline 8 & 3.6 & 4.8 & 0.6 & 0.3 & 0.9 \\
\hline 9 & 5.2 & 4.0 & 2.2 & 1.4 & 2.2 \\
\hline 10 & 4.8 & 1.6 & 1.9 & 1.1 & 1.9 \\
\hline 11 & 1.4 & 5.4 & 1.0 & 5.1 & 1.4 \\
\hline 12 & 5.5 & 4.6 & 1.1 & 3.7 & 0.5 \\
\hline 13 & 4.9 & 3.0 & 0.5 & 2.2 & 2.6 \\
\hline 14 & 5.6 & 3.0 & 0.8 & 1.9 & 2.7 \\
\hline 15 & 5.3 & 4.8 & 3.7 & 0.3 & 1.1 \\
\hline 16 & 4.7 & 0.9 & 2.9 & 1.5 & 0.8 \\
\hline 17 & 3.8 & 5.8 & 1.1 & 1.7 & 2.9 \\
\hline 18 & 4.6 & 3.2 & 0.7 & 4.8 & 4.8 \\
\hline 19 & 5.4 & 4.7 & 1.1 & 3.6 & 1.0 \\
\hline 20 & 4.8 & 4.9 & 3.3 & 0.3 & 0.3 \\
\hline
\end{tabular}




\section{APPENDIX B}

\section{STATISTICAL RESULTS}


STATISTICAL RESULTS

Summary of Data

\begin{tabular}{|l|l|l|l|}
\hline Time (hours) & N Rows & $\begin{array}{l}\text { Mean Leakage } \\
(\mathrm{mm})\end{array}$ & $\begin{array}{l}\text { Std Dev } \\
\text { (Leakage) }\end{array}$ \\
\hline 0 & 20 & 4.2 & 1.3 \\
\hline 1 & 20 & 3.8 & 1.3 \\
\hline 4 & 20 & 1.7 & 1.2 \\
\hline 24 & 20 & 1.7 & 1.5 \\
\hline 168 & 20 & 1.6 & 1.2 \\
\hline
\end{tabular}

\section{Response leakage}

\section{Whole Model}

Actual by Predicted Plot

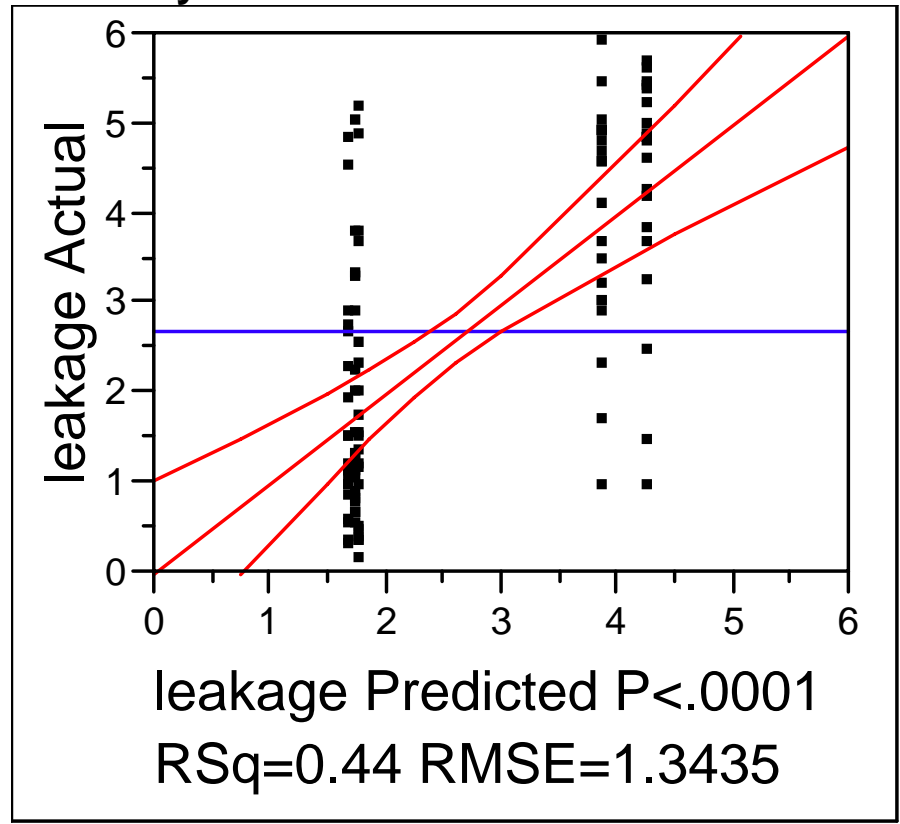

Summary of Fit

\begin{tabular}{|l|r|}
\hline & \\
\hline RSquare & 0.4366 \\
\hline RSquare Adj & 0.412878 \\
\hline Root Mean Square Error & 1.343528 \\
\hline Mean of Response & 2.67976 \\
\hline Observations (or Sum Wgts) & 100 \\
\hline
\end{tabular}


Analysis of Variance

\begin{tabular}{|l|r|r|r|r|}
\hline Source & DF & Sum of Squares & Mean Square & F Ratio \\
\hline Model & 4 & 132.88730 & 33.2218 & 18.4048 \\
\hline Error & 95 & 171.48130 & 1.8051 & Prob $>$ F \\
\hline C. Total & 99 & 304.36860 & & $<.0001$ \\
\hline
\end{tabular}

\section{Effect Tests}

\begin{tabular}{|l|r|r|r|r|r|r|}
\hline Source & Nparm & DF & Sum of Squares & F Ratio & Prob > F \\
\hline Time & 4 & 4 & 132.88730 & 18.4048 & $<.0001$ \\
\hline
\end{tabular}

\section{Time}

\section{Leverage Plot}

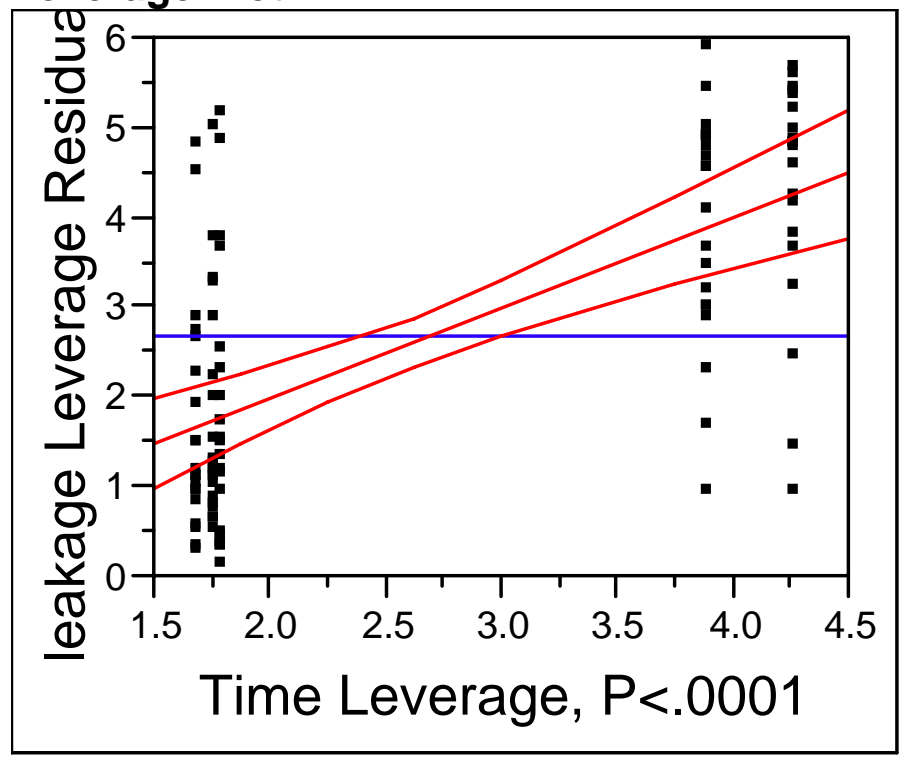

\section{Least Squares Means Table}

\begin{tabular}{|l|r|r|r|}
\hline Level & Least Sq Mean & Std Error & Mean \\
\hline 0 & 4.2726500 & 0.30042190 & 4.27265 \\
\hline 1 & 3.8941000 & 0.30042190 & 3.89410 \\
\hline 4 & 1.7625000 & 0.30042190 & 1.76250 \\
\hline 24 & 1.7852000 & 0.30042190 & 1.78520 \\
\hline 168 & 1.6843500 & 0.30042190 & 1.68435 \\
\hline
\end{tabular}




\section{LS Means Plot}

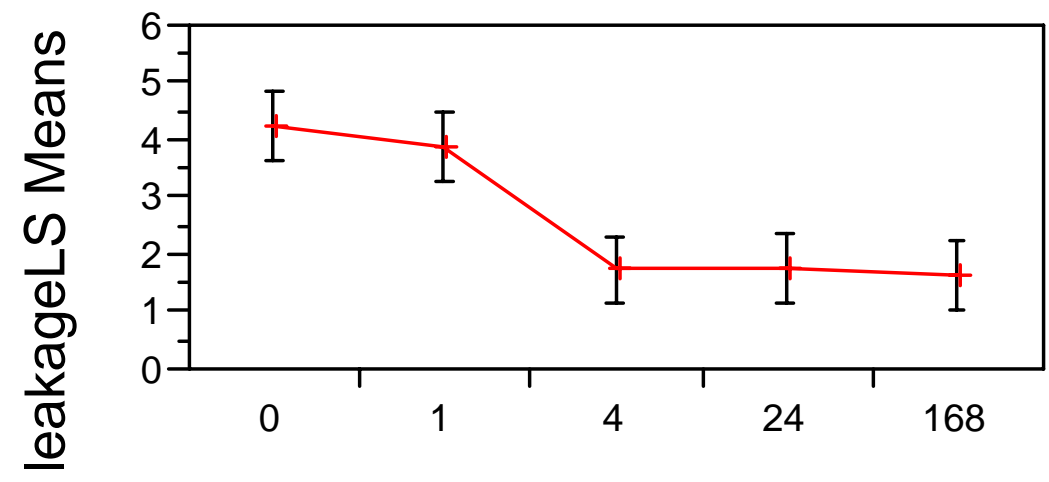

Time

Oneway Analysis of leakage By Time

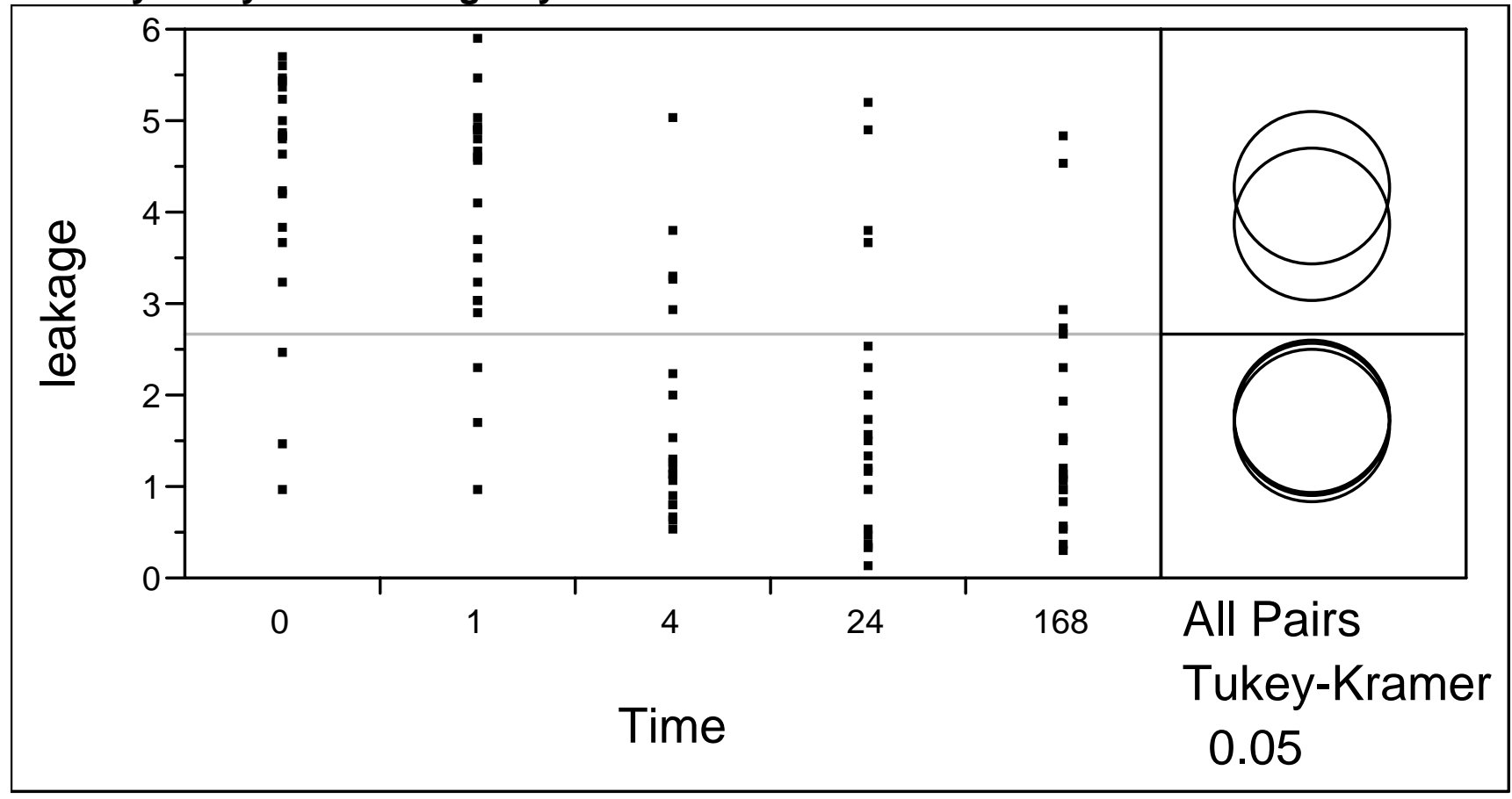

Means Comparisons

Comparisons for all pairs using Tukey-Kramer HSD

\begin{tabular}{|c|c|c|c|c|c|}
\hline & \multicolumn{2}{|c|}{ Alpha } & & & \\
\hline 2.780 & & & & & \\
\hline Abs(Dif)-LSD & 0 & 1 & 24 & 4 & 168 \\
\hline 0 & -1.1815 & -0.8029 & 1.3060 & 1.3287 & 1.4068 \\
\hline 1 & -0.8029 & -1.1815 & 0.9274 & 0.9501 & 1.0283 \\
\hline 24 & 1.3060 & 0.9274 & -1.1815 & -1.1588 & -1.0806 \\
\hline 4 & 1.3287 & 0.9501 & -1.1588 & -1.1815 & -1.1033 \\
\hline 168 & 1.4068 & 1.0283 & -1.0806 & -1.1033 & -1.1815 \\
\hline
\end{tabular}

Positive values show pairs of means that are significantly different. 


\begin{tabular}{|l|l|l|r|}
\hline Level & & & Mean \\
\hline 0 & $\mathrm{~A}$ & & 4.2726500 \\
\hline 1 & $\mathrm{~A}$ & & 3.8941000 \\
\hline 24 & & $\mathrm{~B}$ & 1.7852000 \\
\hline 4 & & $\mathrm{~B}$ & 1.7625000 \\
\hline 168 & & $\mathrm{~B}$ & 1.6843500 \\
\hline
\end{tabular}

Levels not connected by same letter are significantly different

\begin{tabular}{|l|l|r|r|r|l|l|}
\hline Level & - Level & Difference & Lower CL & Upper CL & Difference \\
\hline 0 & 168 & 2.588300 & 1.40682 & 3.769780 & \\
\hline 0 & 4 & 2.510150 & 1.32867 & 3.691630 & \\
\hline 0 & 24 & 2.487450 & 1.30597 & 3.668930 & \\
\hline 1 & 168 & 2.209750 & 1.02827 & 3.391230 & \\
\hline 1 & 4 & 2.131600 & 0.95012 & 3.313080 & \\
\hline 1 & 24 & 2.108900 & 0.92742 & 3.290380 & \\
\hline 0 & 1 & 0.378550 & -0.80293 & 1.560030 & $\mid$ \\
\hline 24 & 168 & 0.100850 & -1.08063 & 1.282330 & \\
\hline 4 & 168 & 0.078150 & -1.10333 & 1.259630 & $\mid$ \\
\hline 24 & 4 & 0.022700 & -1.15878 & 1.204180 & $\mid$ \\
\hline
\end{tabular}




\section{CURRICULUM VITAE}

\section{MARK DANIEL RICHEY, DMD}

\section{Education}

West Virginia University

Master of Science, Endodontics 2008

Morgantown, WV

University of Pennsylvania

Doctor of Dental Medicine

2005

Philadelphia, PA

Pennsylvania State University

Bachelor of Science, Biology

2000

University Park, PA

Associate Dentist

Dr. Jonathan Krisner

New Salem, PA

Associate Dentist

Dr. Diana Frum

Westover, WV

General Practice Residency

2005-2006

Allegheny General Hospital

Pittsburgh, PA 